\title{
Infestation of potato tubers by a Streptomyces scabies depending on application of herbicides and biostimulants
}

\author{
Porażenie bulw ziemniaka Streptomyces scabies w zależności \\ od zastosowanych herbicydów i biostymulatorów
}

\author{
Krystyna Zarzecka ${ }^{1}$, Marek Gugała ${ }^{1}$, Iwona Mystkowska²*, Anna Sikorska
}

\section{Summary}

In the years 2012-2014 field experiment was conducted in the town of Wojnów in the Masovian Voivodeship. The aim of the study was to determine the occurrence of common scab on edible potato tubers depending on the herbicides and herbicides with biostimulators. In the experiment, two factors were examined: the first order factor were potato varieties: Bartek, Gawin, Honorata, while the second order factor was five ways of using herbicides and herbicides with biostimulators: control object - mechanical care, Harrier 295 ZC, Harrier 295 ZC and Kelpak SL, Sencor 70 WG and Sencor 70 WG and Asahi SL. The assessment of tuber infestation with scab was made using a 9-point scale on 100 randomly selected tubers from individual objects of the experiment. Herbicides and herbicides with biostimulators used in potato cultivation significantly reduced the occurrence of common scab on tubers and reduced the average degree of sample infestation and infected tubers.

Key words: common scab, biostimulators, Harrier 295 ZC, Sencor 70 WG, Solanum tuberosum L.

\section{Streszczenie}

W latach 2012-2014 przeprowadzono doświadczenie polowe, zlokalizowane w miejscowości Wojnów, położonej w województwie mazowieckim. Celem badań było określenie występowania parcha zwykłego na bulwach ziemniaka jadalnego w zależności od zastosowanych herbicydów i herbicydów z biostymulatorami. W doświadczeniu badano dwa czynniki: czynnikiem I rzędu były odmiany ziemniaka: Bartek, Gawin, Honorata, natomiast czynnikiem II rzędu - pięć sposobów stosowania herbicydów i herbicydów z biostymulatorami: obiekt kontrolny - pielęgnacja mechaniczna, Harrier 295 ZC, Harrier 295 ZC i Kelpak SL, Sencor 70 WG oraz Sencor 70 WG i Asahi SL. Ocenę porażenia bulw parchem zwykłym dokonano za pomocą 9-stopniowej skali, na 100 losowo pobranych bulwach z poszczególnych obiektów eksperymentu. Zastosowane w uprawie ziemniaka herbicydy i herbicydy z biostymulatorami istotnie ograniczały występowanie parcha zwykłego na bulwach oraz zmniejszały średni stopień porażenia próby i średni stopień porażenia bulw porażonych.

Słowa kluczowe: parch zwykły, biostymulatory, Harrier 295 ZC, Sencor 70 WG, Solanum tuberosum L.

\footnotetext{
${ }^{1}$ Uniwersytet Przyrodniczo-Humanistyczny w Siedlcach

Wydział Agrobioinżynierii i Nauk o Zwierzętach, Instytut Rolnictwa i Ogrodnictwa

Prusa 14, 08-110 Siedlce

2Państwowa Szkoła Wyższa im. Papieża Jana Pawła II w Białej Podlaskiej

Wydział Nauk Technicznych, Zakład Rolnictwa

Sidorska 95/97, 21-500 Biała Podlaska

${ }^{3}$ Państwowa Uczelnia Zawodowa im. Ignacego Mościckiego w Ciechanowie

Wydział Inżynierii i Ekonomii, Zakład Rolnictwa

Narutowicza 9, 06-400 Ciechanów

*corresponding author: imystkowska@op.pl

ORCID: 0000-0002-8361-5806
} 


\section{Wstęp / Introduction}

Ziemniak jest rośliną, która w polskim rolnictwie ma kluczowe znaczenie gospodarcze, a wynika ono z jego wielostronnego wykorzystania, wysokiej wartości odżywczej oraz sprzyjających warunków uprawy. W czasie wzrostu i rozwoju rośliny ziemniaka narażone są na liczne patogeny, które mogą obniżać jakość oraz wartość handlową bulw. Jednym z głównych zagrożeń są choroby skórki, do których należą: parch zwykły, parch srebrzysty oraz rizoktonioza (ospowatość) (Zarzecka i wsp. 2013; Jankowska i wsp. 2015; Jeske i wsp. 2015).

Na decyzje odbiorców ziemniaka jadalnego, w sposób bezpośredni wpływa wygląd zewnętrzny bulw, który największe znaczenie odgrywa w przypadku sadzeniaków, ziemniaków jadalnych oraz przeznaczonych dla przemysłu spożywczego. Jedną z groźniejszych chorób jest parch zwykły, który objawia się licznymi strupowatymi zmianami wywoływanymi przez bakterie z rodzaju Streptomyces, a gatunkiem najbardziej rozpowszechnionym jest Streptomyces scabies. Choroba ta przenosi się z sadzeniakami, nie obniża plonu bulw lecz zmniejsza ich jakość, estetykę i może nawet eliminować ziemniaka $\mathrm{z}$ obrotu handlowego (Atiq i wsp. 2013). Według Nowackiego (2006) straty plonu ogólnego spowodowane wystąpieniem na bulwach parcha zwykłego mogą osiągnąć nawet $8 \%$. Na stopień porażenia bulw ziemniaka chorobami oddziałuje wiele czynników. Jednym z ważniejszych są zabiegi agrotechniczne, które mogą częściowo ograniczyć lub redukować rozwój chorób skórki (Lenc 2009). Duże znaczenie mają występujące w danym roku warunki meteorologiczne. Według Jankowskiej i wsp. (2015) nasilenie występowania S. scabies na bulwach powodowane jest niedoborem opadów, suchym i ciepłym stanowiskiem oraz uprawą na słabych piaszczystych i alkalicznych glebach.

W ostatnich latach chcąc stworzyć roślinom najkorzystniejsze warunki do wzrostu i rozwoju, oprócz herbicydów, które stanowią obecnie stały element w technologii uprawy roślin uprawnych, stosowane są preparaty klasyfikowane jako biostymulatory, które zmniejszają presję na środowi- sko (Farouk 2015; Kowalska 2016; Głosek-Sobieraj i wsp. 2018; Drobek i wsp. 2019). Preparaty te zwiększają swoiste mechanizmy obronne oraz odpornościowe roślin, poprawiając ogólny stan zdrowia, witalność i wzrost roślin oraz chroniąc je przed infekcjami (Gugała i wsp. 2013; Matyjaszczyk 2015; Kołodziejczyk 2016; Drobek i wsp. 2019). Stosowanie herbicydów oraz herbicydów z biostymulatorami przyczynia się do zmniejszenia występowania zachwaszczenia na plantacji ziemniaka, minimalizuje występowanie wad wewnętrznych i zewnętrznych na bulwach (Gugała i wsp. 2017, 2018), poprawia zdrowotność roślin i przyczynia się do wzbudzenia naturalnych sił obronnych roślin (Walters i wsp. 2011).

Celem badań było określenie wpływu herbicydów i herbicydów stosowanych $\mathrm{z}$ biostymulatorami na porażenie bulw ziemniaka parchem zwykłym.

\section{Materiały i metody / Materials and methods}

Doświadczenie przeprowadzono w latach 2012-2014 w miejscowości Wojnów (52¹2’59’N , 22³4’37’E), położonej w województwie mazowieckim. Eksperyment zlokalizowano na glebie lekkiej, o pH wahającym się od 5,60 do $6,35 \mathrm{w} 1 \mathrm{M} \mathrm{KCl}$, zaliczanej do kompleksu żytniego bardzo dobrego, klasy bonitacyjnej IVb (tab. 1). Doświadczenie założono jako dwuczynnikowe metodą losowanych podbloków w trzech powtórzeniach. Pierwszym czynnikiem były odmiany ziemniaka: Bartek, Gawin, Honorata, a drugim sposoby stosowania herbicydów i herbicydów z biostymulatorami: 1. obiekt kontrolny, ochrona obejmowała wyłącznie pielęgnację mechaniczną, wykonano do wschodów dwukrotne obredlanie i jednokrotne obredlanie $\mathrm{z}$ bronowaniem, a po wschodach dwukrotne obredlanie, 2. pielęgnacja mechaniczno-chemiczna - do wschodów wykonano jednokrotne obredlanie oraz aplikowano herbicyd Harrier 295 ZC (linuron + chlomazon) w dawce $2,0 \mathrm{dm}^{3} /$ ha, 3. pielęgnacja mechaniczno-chemiczna - do wschodów jednokrotne obredlanie oraz zastosowanie herbicydu Harrier 295 ZC (linuron + chlomazon) w dawce $2,0 \mathrm{dm}^{3} /$ ha, a po wschodach dwu-

Tabela 1. Kwasowość gleby i zawartość dostępnych form gleby: potasu, fosforu, magnezu i materii organicznej

Table 1. The acidity of the soil and the content of available forms of soil potassium, phosphorus, magnesium and organic matter

\begin{tabular}{|c|c|c|c|c|c|}
\hline $\begin{array}{l}\text { Lata } \\
\text { Years }\end{array}$ & $\begin{array}{c}\mathrm{pH} \\
{\left[1 \mathrm{~mol} \mathrm{KCl} / \mathrm{dm}^{3}\right]}\end{array}$ & $\begin{array}{c}\text { Zawartość K } \\
\text { Content of K } \\
{[\mathrm{mg} / \mathrm{kg}]} \\
\end{array}$ & $\begin{array}{c}\text { Zawartość P } \\
\text { Content of P } \\
{[\mathrm{mg} / \mathrm{kg}]}\end{array}$ & $\begin{array}{c}\text { Zawartość } \mathrm{Mg} \\
\text { Content of } \mathrm{Mg} \\
{[\mathrm{mg} / \mathrm{kg}]}\end{array}$ & $\begin{array}{c}\text { Materia organiczna } \\
\text { Organic matter } \\
{[\mathrm{g} / \mathrm{kg}]}\end{array}$ \\
\hline 2012 & $\begin{array}{c}5,60 \\
\text { lekko kwaśny } \\
\text { slightly acidic }\end{array}$ & $\begin{array}{c}149,4 \\
\text { bardzo wysoka } \\
\text { very high }\end{array}$ & $\begin{array}{c}68,6 \\
\text { wysoka } \\
\text { high }\end{array}$ & $\begin{array}{c}50,0 \\
\text { wysoka } \\
\text { high }\end{array}$ & 15,0 \\
\hline 2013 & $\begin{array}{c}5,60 \\
\text { lekko kwaśny } \\
\text { slightly acidic }\end{array}$ & $\begin{array}{c}129,0 \\
\text { wysoka } \\
\text { high } \\
\end{array}$ & $\begin{array}{c}73,4 \\
\text { wysoka } \\
\text { high } \\
\end{array}$ & $\begin{array}{c}51,0 \\
\text { wysoka } \\
\text { high }\end{array}$ & 16,0 \\
\hline 2014 & $\begin{array}{c}6,35 \\
\text { zasadowy } \\
\text { neutral }\end{array}$ & $\begin{array}{c}149,4 \\
\text { średnia } \\
\text { medium }\end{array}$ & $\begin{array}{c}110,0 \\
\text { bardzo wysoka } \\
\text { very high }\end{array}$ & $\begin{array}{c}56,0 \\
\text { wysoka } \\
\text { high }\end{array}$ & 18,7 \\
\hline
\end{tabular}


krotne opryskiwanie biostymulatorem Kelpak SL (ekstrakt $\mathrm{z}$ alg Ecklonia maxima) w dawkach po $2,0 \mathrm{dm}^{3} /$ ha, 4. pielęgnacja mechaniczno-chemiczna - do wschodów dwukrotne obredlanie, jednokrotne obredlanie $\mathrm{z}$ bronowaniem i herbicyd Sencor $70 \mathrm{WG}$ (metrybuzyna) w dawce $1,0 \mathrm{~kg} / \mathrm{ha}, 5$. pielęgnacja mechaniczno-chemiczna - do wschodów dwukrotne obredlanie, jednokrotne obredlanie $\mathrm{z}$ bronowaniem oraz aplikacja herbicydu Sencor 70 WG (metrybuzyna) w ilości $1,0 \mathrm{~kg} / \mathrm{ha}$, a po wschodach dwukrotne opryskiwanie biostymulatorem Asahi SL w (para-nitrofenolan sodu, orto-nitrofenolan sodu, 5-nitrogwajakolan sodu) w dawkach po 1,0 dm³/ha.

Ziemniaki sadzono ręcznie pod znacznik w rozstawie $67,5 \times 37 \mathrm{~cm}, \mathrm{w}$ trzeciej dekadzie kwietnia (lata 2012, 2014) i w pierwszej dekadzie maja (2013 rok). Każde poletko stanowiło pięć redlin. Pomiędzy poletkami pozostawiono pasy ochronne. Dane dotyczące zabiegów agrotechnicznych i prowadzenia doświadczenia przedstawiono we wcześniejszej pracy Gugały i wsp. (2016). Przedplonem pod ziemniaki w poszczególnych latach badań była pszenica ozima. Po zbiorze przedplonu wykonywano zespół uprawek pożniwnych. Jesienią każdego roku poprzedzającego sadzenie stosowano nawożenie naturalne w postaci obornika w ilości 25,0 t/ha oraz nawożenie mineralne fosforowo-potasowe $\mathrm{w}$ ilości $\mathrm{P}-44,0\left(100 \mathrm{P}_{2} \mathrm{O}_{5} \times 0,44\right) \mathrm{kg} / \mathrm{ha}$ (lubofos pod ziemniaki 7\%) i K $-124,5\left(150 \mathrm{~K}_{2} \mathrm{O} \times 0,83\right) \mathrm{kg} / \mathrm{ha}$ (lubofos pod ziemniaki $25 \%$ ). Nawozy te przyorano orką przedzimową. Nawozy azotowe wysiewano wiosną w ilości N $-100 \mathrm{~kg} / \mathrm{ha}$ (saletrzak 27\%) i wymieszano je z glebą za pomocą kultywatora.

Ocenę zdrowotności bulw wykonano bezpośrednio po zbiorze na 100 bulwach, które pobrano losowo z każdego poletka (45 prób). W doświadczeniu określono procentowy udział bulw porażonych, średni stopień porażenia próby oraz średni stopień porażenia bulw porażonych. Porażenie bulw $S$. scabies oceniano według 9-stopniowej skali, gdzie 9 - oznacza wartość najlepszą, 5,5 - wartość średnią, natomiast 1 - najgorszą. Uprawiane w doświadczeniu odmiany cechowały się podwyższoną odpornością na parcha zwykłego: Bartek - 6,0, Gawin - 7,8, Honorata - 7,4 (Chotkowski i Stypa 2010; Stefaniak 2015). Uzyskane wyniki badań opracowano statystycznie za pomocą analizy wariancji, $\mathrm{a}$ istotność różnic przy poziomie $\mathrm{p}=0,05$ porównywano za pomocą testu Tukeya.

Warunki meteorologiczne w trzech latach badań przedstawiono w tabeli 2. Średnie temperatury powietrza we

Tabela 2. Warunki pogodowe podczas wegetacji ziemniaka (2012-2014)

Table 2. Weather conditions during of potato vegetation (2012-2014)

\begin{tabular}{|c|c|c|c|c|c|c|c|}
\hline \multirow{2}{*}{$\begin{array}{l}\text { Lata } \\
\text { Years }\end{array}$} & \multicolumn{7}{|c|}{ Miesiące - Months } \\
\hline & IV & $\mathrm{V}$ & VI & VII & VIII & IX & IV-IX \\
\hline \multicolumn{8}{|c|}{ Temperatura - Temperature $\left[{ }^{\circ} \mathrm{C}\right]$} \\
\hline 2012 & 8,9 & 14,6 & 16,3 & 20,7 & 18,0 & 14,1 & 15,4 \\
\hline 2013 & 7,4 & 15,3 & 18,0 & 19,0 & 18,8 & 11,7 & 15,0 \\
\hline 2014 & 9,8 & 13,5 & 15,4 & 20,8 & 18,1 & 14,1 & 15,3 \\
\hline $\begin{array}{l}\text { Średnia wieloletnia } \\
(1987-2000) \\
\text { Multiyear mean } \\
(1987-2000)\end{array}$ & 7,8 & 12,5 & 17,2 & 19,2 & 18,5 & 13,1 & 14,7 \\
\hline \multicolumn{8}{|c|}{ Opady - Rainfall [mm] } \\
\hline 2012 & 29,9 & 53,4 & 76,2 & 43,0 & 51,0 & 11,4 & 264,9 \\
\hline 2013 & 36,0 & 105,9 & 98,8 & 91,3 & 15,0 & 94,3 & 441,3 \\
\hline 2014 & 45,0 & 92,7 & 55,4 & 10,0 & 105,7 & 26,3 & 335,1 \\
\hline $\begin{array}{l}\text { Średnia wieloletnia } \\
(1987-2000) \\
\text { Multiyear mean } \\
(1987-2000)\end{array}$ & 38,6 & 44,1 & 52,4 & 49,8 & 43,0 & 47,3 & 275,2 \\
\hline \multicolumn{8}{|c|}{ Współczynnik hydrotermiczny Sielianinowa $(\mathrm{K})$ - Sielianinov’s hydrothermic coefficient $(\mathrm{K})$} \\
\hline 2012 & 1,10 & 1,20 & 1,60 & 0,69 & 0,94 & 0,27 & 0,95 \\
\hline 2013 & 1,60 & 2,30 & 1,80 & 1,60 & 0,30 & 2,70 & 1,60 \\
\hline 2014 & 1,50 & 2,30 & 1,20 & 0,16 & 1,90 & 0,62 & 1,20 \\
\hline
\end{tabular}

Wartość współczynnika (K) - Coefficient value (K) (Skowera i wsp. 2014)

$\leq 0,40$ - skrajnie suchy - extremely dry

$0,4<\mathrm{K} \leq 0,7$ - bardzo suchy - very dry

$0,70<\mathrm{K} \leq 1,0-$ suchy - dry

$1,0<\mathrm{K} \leq 1,3-$ dość suchy - rather dry

$1,3<\mathrm{K} \leq 1,6$ - optymalny - optimal

$1,6<\mathrm{K} \leq 2,0-$ umiarkowanie wilgotny - rather humid

$2,0<\mathrm{K} \leq 2,5$ - wilgonty - wet

$2,5<\mathrm{K} \leq 3,0$ - bardzo wilgonty - very humid

$\mathrm{K}>3,0$ - skrajnie wilgotny - extremey humid 
wszystkich latach badań były wyższe od średniej z okresu wieloletniego. Suma opadów w 2012 r. była mniejsza, a w latach 2013 i 2014 większa od średniej z lat 1980-2009. Na podstawie średnich temperatur powietrza i sum opadów obliczono współczynnik hydrotermiczny Sielianinowa (Molga 1986).

\section{Współczynnik hydrotermiczny \\ $\mathrm{K}=$ suma opadów $\times 10$ suma temperatur}

Według współczynnika hydrotermicznego rok 2012 był suchy, 2013 optymalny, a 2014 dość suchy (Skowera i wsp. 2014). O gromadzeniu składników w bulwach odmian średnio wczesnych decydowały głównie warunki hydrotermiczne panujące w lipcu i sierpniu.

\section{Wyniki i dyskusja / Results and discussion}

Badania własne wykazały istotny wpływ metod stosowania herbicydów i biostymulatorów oraz warunków atmosferycznych w latach badań na procentowy udział bulw porażonych parchem zwykłym, średni stopień porażenia próby i średni stopień porażenia bulw porażonych (tab. 3-6). Na bulwach wszystkich uprawianych odmian ziemniaka zmniejszało się występowanie parcha zwykłego pod wpływem zastosowanych herbicydów i herbicydów $\mathrm{z}$ biostymulatorami. $\mathrm{W}$ doświadczeniu przeciętny procentowy udział bulw z objawami parcha zwykłego wynosił 6,3\%, średni stopień porażenia próby 8,79 , a średni stopień porażenia bulw 6,53 w skali 1-9 (tab. 3-5).

Na obiektach doświadczalnych, pielęgnowanych mechaniczno-chemicznie, które opryskiwano herbicydem z biostymulatorem (obiekt 3. i 5.) odnotowano mniejszy procentowy udział bulw porażonych parchem zwykłym, średni stopień porażenia próby oraz średni stopień porażenia bulw niż na obiektach, na których zastosowano pielęgnację mechanicz- ną (obiekt 1.) i ochronę chemiczną, aplikując sam herbicyd (obiekt 2. i 4.), co wskazuje na to, że stosowanie herbicydu z biostymulatorem zmniejsza występowanie chorób bulw ziemniaka. W badaniach Gugały i wsp. (2018) stwierdzono pozytywny wpływ stosowania herbicydów i biostymulatorów, które ograniczały występowanie zewnętrznych oraz wewnętrznych defektów bulw w porównaniu z pielęgnacją mechaniczną. Wpływ stosowania biopreparatu badali również Kurzawińska i Mazur (2008), którzy stwierdzili, że preparat ten istotnie ograniczal procentowe porażenie bulw parchem zwykłym. Autorzy donieśli, że stan zdrowotny bulw ziemniaka po zbiorze zależał od rodzaju użytego środka chwastobójczego i biostymulatora.

Najmniejszy procentowy udział bulw z objawami $S$. scabies, stopień porażenia próby oraz stopień porażenia bulw wystąpił u odmiany Bartek, a największy u odmiany Gawin. Wskazuje to, że przy doborze odmian do produkcji należy sprawdzić odporność na choroby. Różnice w stopniu porażenia odmian opisywali również inni autorzy: Lenc (2009) oraz Atiq i wsp. (2013).

Ponadto Sawicka i Krochmal-Marczak (2009) oraz Sadowski i wsp. (2004) stwierdzili, że zróżnicowanie w nasileniu parcha zwykłego w większym stopniu zależy od roku prowadzenia badań aniżeli od odmian. Jak wynika z badań własnych zainfekowanie bulw ziemniaka parchem zwykłym jest uwarunkowane genetycznie, ale w dużym stopniu zależy od warunków pogodowych panujących w latach prowadzenia badań. Warunki pogodowe miały istotny wpływ na procentowy udział bulw porażonych patogenem, średni stopień porażenia próby i stopień porażenia bulw. Najmniejszy procent bulw porażonych parchem zwykłym odnotowano w 2013 roku (tab. 6), w którym średnia temperatura była najniższa $\mathrm{w}$ stosunku do pozostałych lat badań i wynosiła $15,0^{\circ} \mathrm{C}$, i był to rok najbardziej wilgotny, w którym współczynnik hydrotermiczny Sielianinowa wynosił 1,6. Natomiast największy procent bulw porażonych parchem zwy-

Tabela 3. Procentowy udział bulw porażonych parchem zwykłym w zależności od odmiany i sposobów stosowania herbicydów i biostymulatorów

Table 3. Percentage of tubers infested by a common scab depending on the cultivar and methods of application of herbicides and biostimulants

\begin{tabular}{|c|c|c|c|c|}
\hline \multirow{3}{*}{$\begin{array}{l}\text { Sposoby stosowania herbicydów i biostymulatorów } \\
\text { Methods of application of herbicides and biostimulants }\end{array}$} & \multicolumn{4}{|c|}{ Procent bulw porażonych - Percentage of infested tubers } \\
\hline & \multicolumn{3}{|c|}{ odmiany - cultivars } & \multirow{2}{*}{$\begin{array}{l}\text { średnio } \\
\text { mean }\end{array}$} \\
\hline & Bartek & Gawin & Honorata & \\
\hline $\begin{array}{l}\text { Obiekt kontrolny - pielęgnacja mechaniczna } \\
\text { Control object - mechanical weeding }\end{array}$ & 9,2 & 11,2 & 12,1 & $10,8 \mathrm{a}$ \\
\hline Harrier $295 \mathrm{ZC} 2,0 \mathrm{dm}^{3} / \mathrm{ha}$ & 5,7 & 5,0 & 6,8 & $5,8 \mathrm{~b}$ \\
\hline Harrier $295 \mathrm{ZC} 2,0 \mathrm{dm}^{3} / \mathrm{ha}+$ Kelpak SL 4,0 dm $/ \mathrm{ha}$ & 5,7 & 5,8 & 3,5 & $5,0 \mathrm{c}$ \\
\hline Sencor $70 \mathrm{WG} 1,0 \mathrm{~kg} / \mathrm{ha}$ & 6,1 & 6,2 & 4,8 & $5,7 \mathrm{bc}$ \\
\hline Sencor $70 \mathrm{WG}$ 1,0 kg/ha+ Asahi SL $1,5 \mathrm{dm}^{3} / \mathrm{ha}$ & 4,4 & 4,0 & 3,9 & $4,1 \mathrm{c}$ \\
\hline Średnio - Mean & 6,2 & 6,4 & 6,2 & 6,3 \\
\hline
\end{tabular}

Wartości oznaczone tymi samymi literami nie różnią się istotnie - Values marked with the same letters do not differ significantly 
Tabela 4. Średni stopień porażenia próby parchem zwykłym w zależności od odmiany i sposobów stosowania herbicydów i biostymulatorów

Table 4. Mean degree of sample infestation by a common scab depending on the cultivar and methods of application of herbicides and biostimulants weed control method

\begin{tabular}{|c|c|c|c|c|}
\hline \multirow{3}{*}{$\begin{array}{l}\text { Sposoby stosowania herbicydów i biostymulatorów } \\
\text { Methods of application of herbicides and biostimulants }\end{array}$} & \multicolumn{4}{|c|}{$\begin{array}{l}\text { Średni stopień porażenia próby (skala 1-9) } \\
\text { Mean degree of sample infestation (scale 1-9) }\end{array}$} \\
\hline & \multicolumn{3}{|c|}{ odmiany - cultivars } & \multirow{2}{*}{$\begin{array}{l}\text { średnio } \\
\text { mean }\end{array}$} \\
\hline & Bartek & Gawin & Honorata & \\
\hline $\begin{array}{l}\text { Obiekt kontrolny - pielęgnacja mechaniczna } \\
\text { Control object - mechanical weeding }\end{array}$ & 8,59 & 8,82 & 8,77 & $8,57 \mathrm{c}$ \\
\hline Harrier $295 \mathrm{ZC} 2,0 \mathrm{dm}^{3} / \mathrm{ha}$ & 8,79 & 8,83 & 8,89 & $8,79 \mathrm{~b}$ \\
\hline Harrier $295 \mathrm{ZC} 2,0 \mathrm{dm}^{3} / \mathrm{ha}+$ Kelpak SL 4,0 dm $3 / \mathrm{ha}$ & 8,81 & 8,78 & 8,86 & 8,89 a \\
\hline Sencor $70 \mathrm{WG} 1,0 \mathrm{~kg} / \mathrm{ha}$ & 8,88 & 8,88 & 8,89 & $8,82 \mathrm{ab}$ \\
\hline Sencor 70 WG $1,0 \mathrm{~kg} / \mathrm{ha}+$ Asahi SL $1,5 \mathrm{dm}^{3} / \mathrm{ha}$ & 8,77 & 8,78 & 8,79 & $8,88 \mathrm{ab}$ \\
\hline Średnio - Mean & 8,60 & 8,52 & 8,53 & 8,79 \\
\hline
\end{tabular}

Wartości oznaczone tymi samymi literami nie różnią się istotnie - Values marked with the same letters do not differ significantly

Tabela 5. Średni stopień porażenia bulw porażonych parchem zwykłym w zależności od odmiany i sposobów stosowania herbicydów i biostymulatorów

Table 5. Mean degree of tuber infestation by common scab depending on the cultivar and methods of application of herbicides and biostimulants

\begin{tabular}{|c|c|c|c|c|}
\hline \multirow{3}{*}{$\begin{array}{l}\text { Sposoby stosowania herbicydów i biostymulatorów } \\
\text { Methods of application of herbicides and biostimulants }\end{array}$} & \multicolumn{4}{|c|}{$\begin{array}{c}\text { Średni stopień porażenia bulw porażonych (skala 1-9) } \\
\text { Mean degree of sample infestation (scale 1-9) }\end{array}$} \\
\hline & \multicolumn{3}{|c|}{ odmiany - cultivars } & \multirow{2}{*}{$\begin{array}{c}\text { średnio } \\
\text { mean }\end{array}$} \\
\hline & Bartek & Gawin & Honorata & \\
\hline $\begin{array}{l}\text { Obiekt kontrolny - pielęgnacja mechaniczna } \\
\text { Control object - mechanical weeding }\end{array}$ & 5,52 & 5,16 & 5,06 & $5,25 \mathrm{~b}$ \\
\hline Harrier $295 \mathrm{ZC} 2,0 \mathrm{dm}^{3} / \mathrm{ha}$ & 7,37 & 6,71 & 6,12 & $6,73 \mathrm{a}$ \\
\hline Harrier $295 \mathrm{ZC} 2,0 \mathrm{dm}^{3} / \mathrm{ha}+$ Kelpak SL 4,0 dm $3 / \mathrm{ha}$ & 6,95 & 7,10 & 6,73 & $6,93 \mathrm{a}$ \\
\hline Sencor $70 \mathrm{WG} 1,0 \mathrm{~kg} / \mathrm{ha}$ & 7,33 & 6,33 & 6,23 & $6,63 \mathrm{a}$ \\
\hline Sencor 70 WG 1,0 kg/ha + Asahi SL 1,5 dm $3 / \mathrm{ha}$ & 7,83 & 6,89 & 6,60 & $7,11 \mathrm{a}$ \\
\hline Średnio - Mean & $7,00 \mathrm{a}$ & $6,45 \mathrm{ab}$ & $6,15 \mathrm{~b}$ & 6,53 \\
\hline
\end{tabular}

Wartości oznaczone tymi samymi literami nie różnią się istotnie - Values marked with the same letters do not differ significantly

Tabela 6. Porażenie bulw ziemniaka parchem zwykłym w latach badań (w \% i skali 1-9)

Table 6. Infestation of potato tubers by a common scab in the years of study (in \% and scale 1-9)

\begin{tabular}{|c|c|c|c|c|c|}
\hline \multirow{2}{*}{$\begin{array}{l}\text { Wyszczególnienie } \\
\text { Specification }\end{array}$} & \multicolumn{3}{|c|}{$\begin{array}{l}\text { Lata } \\
\text { Years }\end{array}$} & \multirow{2}{*}{$\begin{array}{l}\text { Średnio } \\
\text { Mean }\end{array}$} & \multirow[t]{2}{*}{$\begin{array}{l}\operatorname{NIR}(0,05) \\
\operatorname{LSD}(0.05)\end{array}$} \\
\hline & 2012 & 2013 & 2014 & & \\
\hline $\begin{array}{l}\text { Procent bulw porażonych } \\
\text { Percentage of infested tubers }\end{array}$ & $11,0 \mathrm{a}$ & $3,8 \mathrm{~b}$ & $4,0 \mathrm{~b}$ & 6,30 & 1,9 \\
\hline $\begin{array}{l}\text { Średni stopień porażenia próby (skala 1-9) } \\
\text { Mean degree of sample infestation (scale 1-9) }\end{array}$ & $8,65 \mathrm{~b}$ & $8,87 \mathrm{a}$ & $8,85 \mathrm{a}$ & 8,79 & 0,08 \\
\hline $\begin{array}{l}\text { Średni stopień porażenia bulw porażonych (skala 1-9) } \\
\text { Mean degree of tuber infestation (scale 1-9) }\end{array}$ & $5,96 \mathrm{~b}$ & $6,98 \mathrm{a}$ & $6,65 \mathrm{ab}$ & 6,65 & 0,74 \\
\hline
\end{tabular}

Wartości oznaczone tymi samymi literami nie różnią się istotnie - Values marked with the same letters do not differ significantly

kłym, stopień porażenia próby oraz stopień porażenia bulw odnotowano w 2012 roku. Rok ten charakteryzował się najwyższą temperaturą i najmniejszą sumą opadów 264,9 mm, oraz współczynnikiem hydrotermicznym równym 0,95 , był to rok suchy. Podobny wpływ warunków pogodowych na występowanie parcha zwykłego wykazali inni autorzy: 
Szutkowska i Lutomirska (2002), Wróbel (2003) oraz Lenc (2009). Lutomirska (2008) stwierdziła w swoich badaniach, że głównym czynnikiem, który powodował porażenie parchem zwykłym była temperatura gleby w okresie wiązania bulw.

\section{Wnioski / Conclusions}

1. Procentowy udział bulw porażonych parchem zwykłym, stopień porażenia próby i stopień porażenia bulw pora- żonych był istotnie zróżnicowany w zależności od sposobów stosowania herbicydów i biostymulatorów oraz lat badań.

2. Mniejszy udział procentowy bulw porażonych $S$. scabies oraz mniejszy stopień porażenia próby i porażenia bulw porażonych odnotowano u odmiany Bartek.

3. O występowaniu parcha zwykłego, stopniu porażenia próby i porażeniu bulw porażonych decydowały warunki atmosferyczne panujące $\mathrm{w}$ okresie wegetacji roślin ziemniaka. Wysoka temperatura powietrza i mała wilgotność sprzyjały rozwojowi parcha.

\section{Literatura / References}

Atiq M., Khalid A.R., Hussian W., Nawaz A., Asad S., Ahmad T.M. 2013. Genetic potential of potato germplasm against common scab disease caused by Streptomyces scabies. Pakistan Journal of Phytopathology 25 (01): 27-30.

Chotkowski J., Stypa I. 2010. Odmiany ziemniaków. Charakterystyka tabelaryczna. Zakład Nasiennictwa i Ochrony Ziemniaka, Bonin, 12 ss.

Drobek M., Frąc M., Cybulska J. 2019. Plant biostimulants: importance of the quality and yield of horticultural crops and the improvement of plant tolerance to abiotic stress - a review. Agronomy 9 (6), 335: 1-18. DOI: 10.3390/agronomy9060335

Farouk S. 2015. Imroving growth and productivity of potato (Solanum tuberosum L.) by some biostimulants and lithovit with or without boron. Journal of Plant Production 6 (12): 2187-2206. DOI: 10.21608/jpp.2015.52463

Głosek-Sobieraj M., Cwalina-Ambroziak B., Hamouz K. 2018. The effect of growth regulators and a biostimulator on the health status, yield and yield components of potatoes (Solanum tuberosum L.). Gesunde Pflanzen 70: 1-11. DOI: 10.1007/s10343-017-0407-7

Gugała M., Zarzecka K., Dołęga H., Niewęgłowski M., Sikorska A. 2016. The effect of biostimulants and herbicides on glycoalkaloid accumulation in potato. Plant Soil and Environment 62 (6): 256-260. DOI: 10.17221/187/2016-PSE

Gugała M., Zarzecka K., Sikorska A. 2013. Ocena skuteczności działania herbicydów i ich wpływ na plon handlowy ziemniaka. [Evaluation of herbicide efficiency and their influence on potato marketable yield]. Biuletyn Instytutu Hodowli i Aklimatyzacji Roślin 270: $75-84$

Gugała M., Zarzecka K., Sikorska A., Dołęga H. 2018. Occurrence of defects of potato tubers in conditions of application of herbicides and biostimulants. Acta Scientiarum Polonorum, Agricultura 17 (1): 13-22. DOI: 10.37660/aspagr

Gugała M., Zarzecka K., Sikorska A., Mystkowska I., Dołęga H. 2017. Wpływ herbicydów i biostymulatorów wzrostu na ograniczenie zachwaszczenia i plonowanie ziemniaka jadalnego. [Effect of herbicides and growth biostimulants on weed reduction and yield of edible potato]. Fragmenta Agronomica 34 (4): 59-66.

Jankowska J., Lutomirska B., Pietraszko M. 2015. Występowanie parcha zwykłego na bulwach ziemniaka w zależności od warunków meteorologicznych. Ziemniak Polski 3: 23-29.

Jeske M., Pańka D., Wichrowska D. 2015. Wpływ ochrony chemicznej, nawożenia organicznego oraz użyźniacza glebowego UGmax na zdrowotność bulw ziemniaka. [Effect of chemical protection, organic fertilization and UGmax soil conditioner on health status of potato tubers]. Progress in Plant Protection 55 (1): 92-97. DOI: 10.14199/ppp-2015-016

Kołodziejczyk M. 2016. Effect of nitrogen fertilization and microbial preparations on quality and storage losses in edible potato. [Wpływ nawożenia azotem i preparatów mikrobiologicznych na kształtowanie się jakości oraz strat przechowalniczych ziemniaka jadalnego]. Acta Agrophysica 23 (1): 67-78.

Kowalska J. 2016. Wpływ nawożenia oraz biostymulatorów mikrobiologicznych na zdrowotność i plonowanie ziemniaka w systemie ekologicznym. [Effect of fertilization and microbiological bio-stimulators on healthiness and yield of organic potato]. Progress in Plant Protection 56 (2): 230-235. DOI: 10.14199/ppp-2016-039

Kurzawińska H., Mazur S. 2008. The effect of bio-preparations on the infestation of tubers by Streptomyces spp. [Wpływ zaprawiania sadzeniaków i opryskiwania roślin ziemniaka preparatami biologicznymi na porażenie bulw przez Streptomyces spp.]. Folia Horticulturae 20 (2): 103-110. DOI: 10.2478/fhort-2013-0119

Lenc L. 2009. Występowanie Streptomyces scabies na bulwach ośmiu odmian ziemniaka uprawianego w systemie ekologicznym i integrowanym. [Occurrence of Streptomyces scabies on tubers of eight potato cultivars grown in organic and integrated cropping system]. Ochrona Środowiska i Zasobów Naturalnych 40: 669-676.

Lutomirska B. 2008. Wpływ czynników meteorologicznych na porażenie bulw ziemniaka parchem zwykłym. [The influence of meteorological factors on tuber infection with common scab]. Progress in Plant Protection/Postępy w Ochronie Roślin 48 (1): 216 -220.

Matyjaszczyk E. 2015. Wprowadzenie biostymulatorów do obrotu handlowego w Polsce. Sytuacja bieżąca i uwarunkowania prawne. [The introduction of biostimulants on the Polish market. The present situation and legal requirements]. Przemysł Chemiczny 94 (10): 1841-1844. DOI: $10.15199 / 62.2015 .10 .40$

Molga M. 1986. Meteorologia rolnicza. Wydanie VII. Państwowe Wydawnictwo Rolnicze i Leśne, Warszawa, 492 ss. ISBN 83-09$-00200-9$

Nowacki W. 2006. Straty plonu handlowego ziemniaków powodowane przez choroby i szkodniki w 2005 roku. [Potato crop yield losses caused by diseases and pests in 2005]. Progress in Plant Protection/Postępy w Ochronie Roślin 46 (1): 193-201.

Sadowski C., Pańka D., Lenc L. 2004. Porównanie zdrowotności bulw i kiełków wybranych odmian ziemniaka uprawianych w systemie ekologicznym. [Comparison of healthiness of tubers and sprouts of some potato cultivars grown in organic system]. Zeszyty Problemowe Postępów Nauk Rolniczych 500: 373-381. 
Sawicka B., Krochmal-Marczak B. 2009. Wpływ stosowania nawozu dolistnego Insol 7 i bioregulatora Asahi SL na zdrowotność bulw kilku odmian ziemniaka. [Influence of foliage application of preparation Insol 7 and Asahi SL on sanitary conditions of tubers of some potato cultivars]. Annales Universitatis Mariae Curie-Skłodowska, Sectio E, Agricultura, 64 (2): 29-38.

Skowera B., Kopcińska J., Kopeć B. 2014. Changes in thermal and precipitation conditions in Poland in 1971-2010. [Zmiany warunków termiczno-opadowych w Polsce w latach 1971-2010]. Annals of Warsaw University of Life Sciences - SGGW, Land Reclamation 46 (2): 153-162. DOI: $10.2478 / \mathrm{sggw}-2014-0013$

Stefaniak E.S. 2015. Charakterystyka odmian ziemniaka jadalnego i skrobiowego. Podlaski Ośrodek Doradztwa Rolniczego w Szepietowie, 24 ss.

Szutkowska M., Lutomirska B. 2002. Wpływ środowiska i niektórych czynników agrotechnicznych na porażenie się bulw ziemniaka parchem zwykłym. Biuletyn Instytutu Hodowli i Aklimatyzacji Roślin 221: 153-166.

Walters D.R., Havis N.D., Paterson L., Taylor J., Walsh D.J. 2011. Cultivar effects on the expression of induced resistance in spring barley. Plant Disease 95 (5): 595-600. DOI: 10.1094/PDIS-08-10-0577

Wróbel S. 2003. Porażenie bulw ziemniaka parchem i rizoktoniozą w zależności od zabiegów stosowanych w nasiennictwie. Biuletyn Instytutu Hodowli i Aklimatyzacji Roślin 228: 283-289.

Zarzecka K., Gugała M., Dołęga H., Baranowska A. 2013. Występowanie Streptomyces scabies na bulwach ziemniaka uprawianego w warunkach pielęgnacji mechaniczno-chemicznej. Biuletyn Instytutu Hodowli i Aklimatyzacji Roślin 269: 79-86. 